\title{
Epigenetic changes in the estrogen receptor $\alpha$ gene promoter: implications in sociosexual behaviors
}

\author{
Ken Ichi Matsuda * \\ Department of Anatomy and Neurobiology, Graduate School of Medical Science, Kyoto Prefectural University of Medicine, Kyoto, Japan
}

\section{Edited by:}

Tomoko Soga, Monash University

Malaysia Campus, Malaysia

Reviewed by:

Kazuhiro Nakamura, Kyoto

University, Japan

Leo T. O. Lee, The University of

Hong Kong, Hong Kong

*Correspondence:

Ken Ichi Matsuda, Department of

Anatomy and Neurobiology,

Graduate School of Medical

Science, Kyoto Prefectural

University of Medicine, 465

Kawaramachi Hirokoji, Kamigyoku,

Kyoto, 602-8566 Japan

e-mail:matsuken@koto.kpu-m.ac.jp
Estrogen action through estrogen receptor $\alpha(E R \alpha)$ is involved in the control of sexual and social behaviors in adult mammals. Alteration of ER $\alpha$ gene activity mediated by epigenetic mechanisms, such as histone modifications and DNA methylation, in particular brain areas appears to be crucial for determining the extents of these behaviors between the sexes and among individuals within the same sex. This review provides a summary of the epigenetic changes in the ER $\alpha$ gene promoter that correlate with sociosexual behaviors.

Keywords: estrogen receptor $\alpha$, epigenetics, histone acetylation, histone deacetylation, DNA methylation, sexual differentiation, sexual behavior, sociosexual behavior

\section{ER $\alpha$ AND ITS GENE PROMOTER}

Estrogen receptor $\alpha(E R \alpha)$ is a member of the nuclear receptor superfamily of ligand-dependent transcription factors that regulate expression of target genes (Evans, 1988; Kawata, 1995; Parker, 1995; Matsuda et al., 2002; McCarthy, 2008). ER $\alpha$ has a typical nuclear receptor structure with at least three functional domains: the ligand-binding domain located in the C-terminal half of the protein, the DNA-binding domain located centrally, and a variable transactivation domain located in the $\mathrm{N}$-terminal region. Upon activation by a ligand, estradiol, ER $\alpha$ forms a homodimer within the nucleus and the dimer complex binds to specific regulatory DNA sequences, which are referred to as estrogen responsive elements (EREs), in promoter or enhancer regions of target genes. After binding to an ERE, the ER $\alpha$ dimer recruits transcription co-factors, which leads to gene activation and transcription. Following transcription, mRNA is translated into proteins that are the ultimate outcome of the hormone responses. Alternatively, accumulating evidence suggests that rapid non-genomic actions of ER $\alpha$ initiated at the plasma membrane through induction of protein phosphorylation-mediated signal transduction pathways are also crucial in estrogenic responses (Vasudevan and Pfaff, 2008; Sakamoto et al., 2012). These characteristics of ER $\alpha$ are common to the other estrogen receptor subtype, ER $\beta$ (Koehler et al., 2005).

Expression of the ER $\alpha$ gene is controlled by multiple promoters located upstream of the first coding exon (Kos et al., 2001; Wilson et al., 2008). In rats, at least four different promoters (C, $0 \mathrm{~S}, 0 \mathrm{~N}$, and $0 \mathrm{~B}$ ) that can initiate transcription have been identified and shown to be utilized in an organ- and tissue-specific manner. The ER $\alpha$ gene transcript from the $\mathrm{OB}$ promoter (also designated as the 1B promoter; Freyschuss and Grandien, 1996; Champagne et al., 2006), which corresponds to the $\mathrm{C}$ promoter in humans and mice, is expressed in brain areas involved in sociosexual behaviors, such as the bed nucleus of the stria terminalis (BNST) (Emery and Sachs, 1976) (Numan, 1996; Numan and Woodside, 2010), the medial preoptic area (MPOA) (Larsson and Heimer, 1964), and hypothalamic and amygdaloid nuclei (Kawata, 1995; McCarthy, 2008), as well as in the anterior pituitary, ovary and uterus (Kato et al., 1998).

\section{ER $\alpha$ IN SOCIOSEXUAL BEHAVIORS}

Gene targeting in mice has shown that ER $\alpha$ contributes to various brain functions, including regulation of sociosexual behaviors in both sexes (Rissman et al., 1997; Tetel and Pfaff, 2010).

\section{FEMALE SEXUAL BEHAVIOR}

$E R \alpha$ knockout $(E R \alpha K O)$ female mice, in which the $E R \alpha$ gene is disrupted in both alleles throughout the body, completely lack lordosis behavior, a typical female sexual behavior (Ogawa et al., 1996). ER $\alpha$ KO females are also deficient in sexual interactions that precede the lordosis response (Ogawa et al., 1998a). The estradiol level in gonadally intact $\mathrm{ER} \alpha \mathrm{KO}$ females is elevated compared to that in wild type females, and thus expression of ER $\alpha$ in the brain is critical for induction of female sexual behavior. However, these studies in ER $\alpha$ KO mice did not clarify whether the deficits were caused by a lack of ER $\alpha$ activation during development or in adulthood.

Spatiotemporal knockdown of ER $\alpha$ mRNA (ER $\alpha \mathrm{KD})$ mediated by infection with adeno-associated virus (AAV) expressing small hairpin (sh) RNA against ER $\alpha$ mRNA has been conducted in adult female mice. When gene silencing was restricted to the bilateral ventromedial nucleus of hypothalamus $(\mathrm{VMH})$, where 
$\mathrm{ER} \alpha$ is strongly expressed, the mice exhibited no sexual behavior (Musatov et al., 2006), indicating that $\mathrm{ER} \alpha$ function in the $\mathrm{VMH}$ in adulthood is a key regulator of female sexual behavior. Female mice in which expression of $\mathrm{ER} \alpha$ was silenced in the MPOA also exhibited significant reduction in receptive and rejective female sexual behaviors (Ribeiro et al., 2012).

\section{MALE SEXUAL BEHAVIOR}

In males, estrogen is produced from testosterone by the enzymatic activity of aromatase in the brain and is known to regulate sexual behavior. Male ER $\alpha \mathrm{KO}$ mice show significant impairment in some components of sexual behavior compared with wild type mice. ER $\alpha \mathrm{KO}$ mice exhibit a normal motivation to mount females, but reduced levels of intromission and no ejaculation (Ogawa et al., 1997; Wersinger et al., 1997; Ogawa et al., 1998b; Scordalakes and Rissman, 2003).

Brain regions responsible for $\mathrm{ER} \alpha$-mediated regulation of male sexual behavior have been examined using ER $\alpha$ KD by AAV infection. Male sexual behavior was greatly reduced when ER $\alpha$ expression was silenced in the MPOA (Sano et al., 2013). In MPOA $\mathrm{ER} \alpha \mathrm{KD}$ mice, mount motivation and intromission were reduced, suggesting that ER $\alpha$ expressed in the MPOA in adulthood is involved in the control of male sexual motivation and behavior. Silencing ER $\alpha$ expression in the VMH also caused a reduction in male sexual behavior, particularly in the number of intromissions (Sano et al., 2013). This result indicates that ER $\alpha$ function in the $\mathrm{VMH}$ is also important for the expression of male sexual behavior.

\section{FEMALE SOCIAL BEHAVIOR}

ER $\alpha$ KO females show increased aggression toward other females (Ogawa et al., 1996). Gonadally intact ER $\alpha$ KO females vigorously attack gonadectomized and steroid-primed female intruder mice. Gonadectomized and steroid-primed ER $\alpha \mathrm{KO}$ females placed in the home cage of males that showed sexual behavior to wild type females showed extreme rejection of male mounts, whereas gonadally intact $\mathrm{ER} \alpha \mathrm{KO}$ females were vigorously attacked by the males (Ogawa et al., 1996, 1998a). Similarly, ER $\alpha$ gene silencing in the VMH caused steroid-primed females to reject males (Spiteri et al., 2010a,b). In contrast, ER $\alpha \mathrm{KD}$ in the MPOA decreased aggression toward male intruders, as well as social investigation behaviors consisting of genital sniffing, touching the back and chasing (Spiteri et al., 2012).

$\mathrm{ER} \alpha$ signaling also contributes to the induction of maternal behavior toward newborn pups. $\mathrm{ER} \alpha \mathrm{KO}$ females exhibited greatly reduced pup retrieval behavior compared with wild type controls (Ogawa et al., 1996). Silencing of ER $\alpha$ mRNA in the MPOA almost completely abolished maternal behaviors, including nursing and licking the pups, and significantly increased latency to pup retrieval (Ribeiro et al., 2012).

\section{MALE SOCIAL BEHAVIOR}

Estradiol contributes to male aggressive behaviors at least partially via $\mathrm{ER} \alpha$. Male-typical offensive attacks are rarely observed in gonadally intact or gonadectomized and androgen-replaced ER $\alpha$ KO males (Ogawa et al., 1997, 1998b). ER $\alpha$ KD in the VMH reduces aggressive behavior, but this effect is not seen for $\mathrm{ER} \alpha \mathrm{KD}$ in the MPOA (Sano et al., 2013).

\section{EPIGENETIC CHANGES IN THE ER $\alpha$ GENE PROMOTER}

Studies using ER $\alpha$ gene targeting techniques suggest that alteration of sensitivity to estrogen by changing the expression level of $\mathrm{ER} \alpha$ in specific brain regions is a crucial feature in the control of sociosexual behaviors.

\section{SEX DIFFERENCE}

The sex of the brain is mostly determined by the effects of androgen and its metabolite, estradiol. In rodents, androgen is transiently secreted from the testes during a critical perinatal period, the so-called androgen surge, and organizes the developing brain into a masculinized phenotype (Arnold and Gorski, 1984; Kawata, 1995; Matsuda et al., 2008; McCarthy, 2008). Androgen does not affect the brain directly; instead masculinization is largely mediated by estradiol converted from testosterone by aromatase in the brain. The presence or absence of brief exposure to estradiol during the perinatal period creates permanent sex differences in the brain including lasting sex differences in the expression of several genes. ER $\alpha$ expression in the preoptic area (POA) is higher in females than in males from postnatal day 2 through adulthood (DonCarlos and Handa, 1994; DonCarlos, 1996; Yokosuka et al., 1997). Thus, how the early effects of estrogen on the developing brain are permanently maintained is a fundamental issue in the study of sexual differentiation of the brain. Epigenetic mechanisms are emerging as important mediators for the maintenance of the hormonal effects (Keverne and Curley, 2008; McCarthy and Crews, 2008; Matsuda et al., 2012).

DNA methylation is a well characterized epigenetic change that contributes widely to transcriptional regulation (Nakao, 2001; Felsenfeld and Groudine, 2003). In the genome, the 5 position of the cytosine pyrimidine ring in the $5^{\prime}$-CpG- $3^{\prime}$ dinucleotide is frequently modified with a methyl group. In general, the extent of CpG methylation in a promoter region is inversely correlated with the transcription level of the gene: higher methylation causes suppressed gene expression. The DNA methylation status of the $\mathrm{CpG}$-rich region in the 1st intron of the ER $\alpha$ gene across the life span has been examined in the POA and the mediobasal hypothalamus $(\mathrm{MBH})$, which includes the VMH (Schwarz et al., 2010). On postnatal day 1 , during the critical period of sexual differentiation, two of seven $\mathrm{CpG}$ sites (one of these sites differs between the $\mathrm{POA}$ and $\mathrm{MBH}$ ) have a significantly lower methylation rate in males than in females in both the POA and $\mathrm{MBH}$ (Figure 1). This difference is a result of estradiol exposure because treatment of females with estradiol $24 \mathrm{~h}$ before sample collection induces a methylation pattern identical to that in males. These site specific modifications of DNA methylation may be involved in the maintenance of $\mathrm{ER} \alpha$ expression in males to facilitate the effect of estradiol during the androgen surge.

The histone acetylation status in the $\operatorname{ER} \alpha$ gene promoter also shows a sex difference during the critical perinatal period. Histone acetylation is a well-characterized epigenetic modification that is important in transcriptional regulation (Kouzarides, 2007; Graff and Tsai, 2013). Histone acetylation neutralizes the positive charge of the histone tail and reduces its attraction to the negatively charged DNA, thereby loosening the nucleosome and allowing access of transcriptional factors, thus enhancing gene transcription. Acetylation levels of histone $\mathrm{H} 4$ at the ER $\alpha$ 


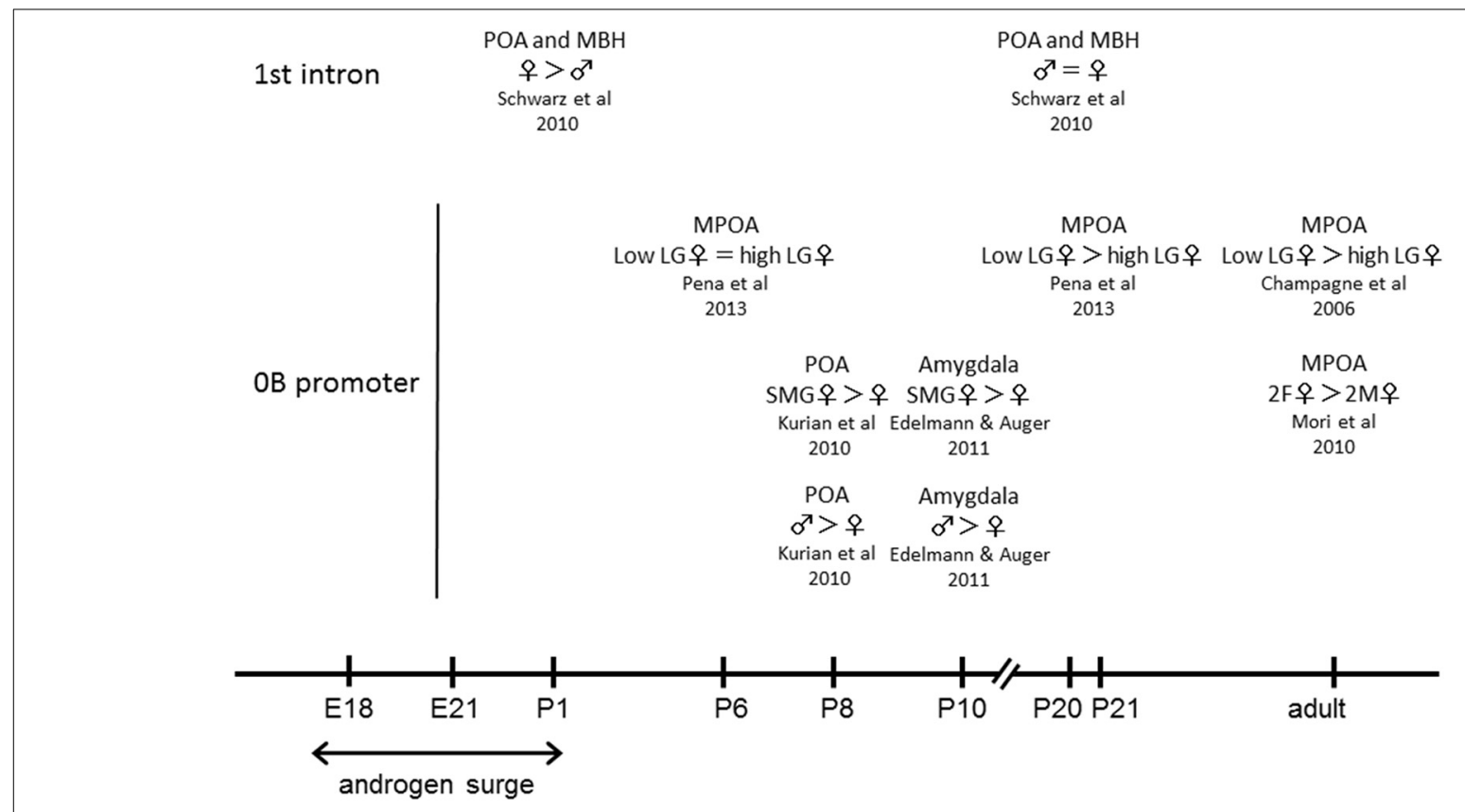

FIGURE 1 | Summary of DNA methylation status in the ER $\alpha$ gene in association with sociosexual behaviors. E, embryonic day; P, postnatal day.

OB promoter in the MPOA are higher in males than females on embryonic day 21 (Matsuda et al., 2011), suggesting prevention of downregulation of ER $\alpha$ expression in males.

The extent of methylation of CpG sites in the 1st intron of the ER $\alpha$ gene increases through development in both male and female MPOA and the sex difference detected on postnatal day 1 is abolished by postnatal day 20 (Schwarz et al., 2010) (Figure 1). In addition, an analysis of DNA methylation of the ER $\alpha$ OB promoter in the POA on postnatal day 8 showed that the average methylation across $17 \mathrm{CpG}$ sites was significantly higher in males compared with females (Kurian et al., 2010) (Figure 1). Two of the $17 \mathrm{CpG}$ sites had significantly greater methylation in males and methylation at 6 other $\mathrm{CpG}$ sites was detected only in males. Estradiol treatment of females in the neonatal period increased methylation of the ER $\alpha$ promoter to a similar level to that in males. These findings suggest that sex differences in ER $\alpha$ gene expression may result from sex differences in DNA methylation patterns. A similar difference of methylation pattern at a specific CpG site in the ER $\alpha$ promoter has been seen in the amygdala (Edelmann and Auger, 2011), a brain area important for social and emotional processing, on postnatal day 10 (Figure 1).

The histone acetylation status is inversely correlated with DNA methylation (Matsuda et al., 2011). Histone H4 acetylation differences in the $\mathrm{ER} \alpha \mathrm{OB}$ promoter on embryonic day 21 were rearranged by postnatal day 3 , at which time acetylation levels in males declined in correspondence with the developmental decrease in testosterone. The acetylation status of histones is controlled by the balance of enzymatic activity of histone acetyltransferases and histone deacetylases (HDACs), which remove the acetyl group from an acetylated histone. Thus, HDAC activity during the early postnatal period may be involved in the regulation of sexually dimorphic ER $\alpha$ expression in the MPOA (Figure 2). HDAC2 and -4, which are expressed in the developing

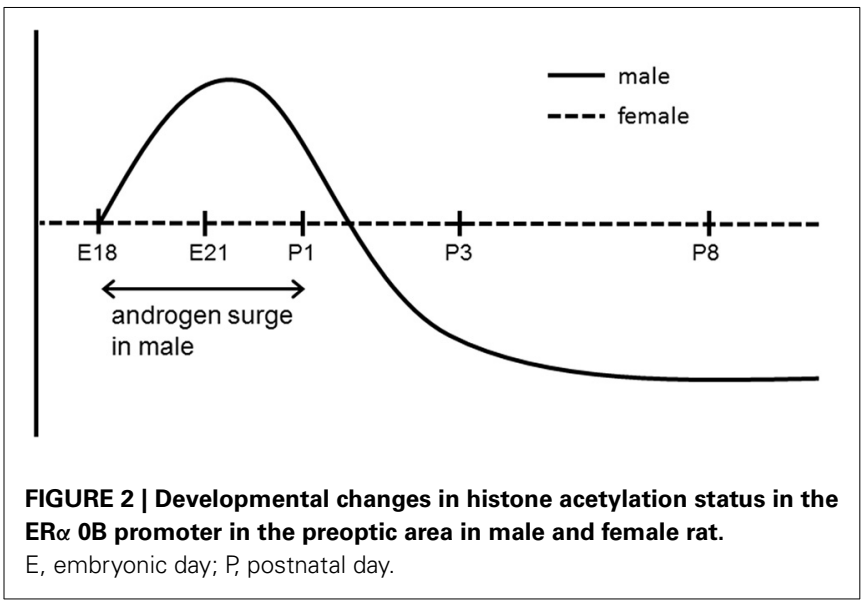

brain and are related to steroid hormone signaling (Leong et al., 2005; Bicaku et al., 2008; Graff and Tsai, 2013), have been identified as candidate molecules regulating this process (Matsuda et al., 2011). The amount of HDAC2 and -4 binding to the $\mathrm{ER} \alpha$ promoter on postnatal day 1 is higher in males than in females in the MPOA, while mRNA levels for HDAC2 and -4 do not differ between the sexes. The importance of HDAC activity in masculinization of the brain in the early postnatal period has been shown by both behavioral and morphological analyses. Inhibition of HDACs in vivo by intracerebroventricular infusion of a HDAC inhibitor (trichostatin A) or an antisense oligodeoxynucleotide directed against mRNA for HDAC2 and -4 in newborn male rats results in significant reduction of male sexual behavior in adulthood (Matsuda et al., 2011). Administration of another HDAC inhibitor (valproic acid) to male mice on postnatal days 1 and 2 eliminates the development of the sex difference in the volume of 
the principal nucleus of the BNST (Murray et al., 2009), which is normally larger in males than females.

These findings provide insights into the molecular mechanisms underlying the developmental consequences of sexually dimorphic ER $\alpha$ expression mediated by epigenetic modifications in the MPOA. During the prenatal androgen surge and subsequent activation of $\mathrm{ER} \alpha$, the acetylation status of histones in the $\mathrm{ER} \alpha$ promoter region is increased in males to maintain $\mathrm{ER} \alpha$ expression. After the androgen surge, inactivation of ER $\alpha$ due to the decline in ligand levels leads to recruitment of HDAC2 and -4 to promoters and the acetylation status of the promoter is reduced (Figure 2). Following the change in histone acetylation, methylation of DNA in the $\mathrm{ER} \alpha$ promoter region is increased to a greater extent in males (Figure 3). This results in continuous lower expression of $\mathrm{ER} \alpha$ compared with females, which is appropriate for execution of masculinized brain functions. These processes are not evident in females due to the absence of an androgen surge, and the consequent higher sensitivity to estrogen with higher expression of $\mathrm{ER} \alpha$ may induce feminized brain functions.

\section{INDIVIDUAL DIFFERENCES}

As described above, perinatal estradiol exposure contributes to lasting sex differences in ER $\alpha$ expression. However, early social experience can also alter ER $\alpha$ expression and associated behaviors. Variations in maternal care in rats distinguished by levels of whole-body licking and grooming (LG) by the dam exert a lasting influence on some neuroendocrine and behavioral characteristics of offspring in adulthood (Francis et al., 1999; Liu et al., 2000; Champagne et al., 2001; Cameron et al., 2005, 2008a,b; Prior et al., 2013). Offspring of dams that display high levels of LG (high LG) exhibit more modest hypothalamic-pituitary-adrenal responses to stress, enhanced cognitive ability, a higher level of maternal behavior, and altered sexual behavior in comparison to offspring of dams with low levels of LG (low LG). The effect of an individual difference in maternal behavior is transmitted across generations (Champagne and Meaney, 2007). Adult female offspring of high LG mothers display increased pup LG, compared

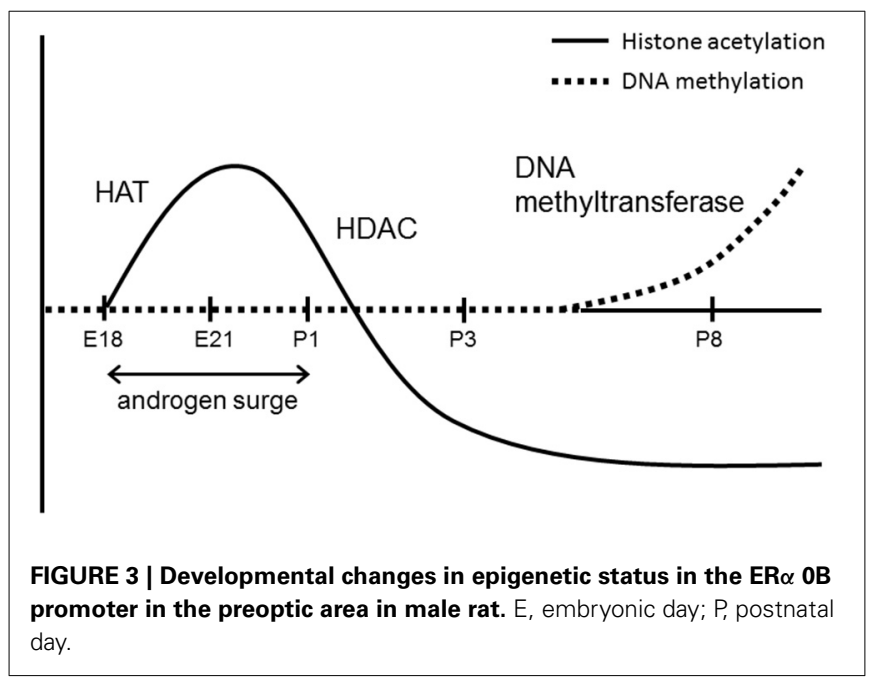

with adult female offspring of low LG mothers. Cross-fostering, in which pups born to high-LG mothers are fostered at birth to low-LG mothers and vice versa, has shown a direct relationship between maternal care actually received and individual characteristics, suggesting that an epigenetic mechanism underlies the transgenerational inheritance of the individual behavioral differences. Variation of neonatal maternal care has been associated with ER $\alpha$ expression (Champagne et al., 2003) and DNA methylation of the $\mathrm{ER} \alpha$ promoter in the MPOA (Champagne et al., 2006). Females that received high LG exhibited elevated ER $\alpha$ expression in adulthood compared with females that received low LG. DNA methylation patterns across the $\mathrm{ER} \alpha 0 \mathrm{~B}$ promoter differed significantly, with 7 of $14 \mathrm{CpG}$ sites exhibiting significantly greater methylation in offspring of low LG dams compared to those from high LG dams (Figure 1). These findings suggest that environmental differences during development are programmed in the brain as a different pattern of epigenetic marks, and that this leads to differences in neuroendocrine and behavioral characteristics after maturity.

Examination of the developmental emergence of LG-mediated epigenetic variation (Pena et al., 2013) indicated a significant difference in DNA methylation rate at the $\mathrm{ER} \alpha 0 \mathrm{~b}$ promoter between high LG and low LG individuals on postnatal day 21, but not on postnatal day 6 (Figure 1), concomitant with the appearance of different ER $\alpha$ mRNA expression. Another epigenetic change, histone methylation, which is catalyzed by histone methyltransferases (HMT), does not change the overall charge of the histone tail, but increases basicity and hydrophobicity, which enhances histone affinity for DNA (Zhang and Reinberg, 2001; Martin and Zhang, 2005). Therefore, histone methylation is generally correlated with transcriptional repression, although methylation of some residues can result in transcriptional activation. Histone $\mathrm{H} 3$ trimethylation at lysine $9(\mathrm{H} 3 \mathrm{~K} 9 \mathrm{me} 3)$ and lysine $4(\mathrm{H} 3 \mathrm{~K} 4 \mathrm{me} 3)$ are epigenetic marks for repressed and active gene transcription, respectively. Comparison of the histone methylation status at the $\mathrm{ER} \alpha 0 \mathrm{~B}$ promoter in the MPOA between high LG and low LG females showed reduced $\mathrm{H} 3 \mathrm{~K} 9 \mathrm{me} 3$ and increased $\mathrm{H} 3 \mathrm{~K} 4 \mathrm{me} 3$ in high LG offspring on postnatal day 21, but not on postnatal day 6 . These findings suggest that the influence of the amount of maternal care on epigenetic effects is apparent between postnatal days 6 and 21.

There is a difference between the sexes in the amount of maternal care. Mother rats preferentially lick and groom their male offspring more than their female offspring (Moore, 1992). This phenomenon implies that somatosensory stimuli associated with maternal grooming, as well as hormone exposure, influence brain masculinization. Simulated maternal grooming (SMG) by stimulation of the anogenital region of female pups with a paintbrush from postnatal days 5 to 7 increases $\mathrm{ER} \alpha$ OB promoter $\mathrm{CpG}$ methylation to a similar level to that in males on postnatal day 8 (Kurian et al., 2010) (Figure 1). ER $\alpha$ expression in the POA on postnatal day 10 was significantly reduced in female pups that received SMG compared to control female pups. These results suggest that maternal grooming may contribute to brain sex organization through programming differences in ER $\alpha$ expression through the epigenetic machinery. A similar effect of SMG on the methylation pattern at a specific CpG site in the $\mathrm{ER} \alpha$ promoter 
has been detected in the amygdala on postnatal day 10 (Edelmann and Auger, 2011) (Figure 1). However, there is a difference in the direction of the effect of maternal care between the two studies: ER $\alpha$ expression was enhanced in high LG females, but reduced in SMG-stimulated females. This may indicate that SMG does not exhibit actual maternal grooming effect, but sensory stimulation during neonatal period has lasting effect on the expression of ER $\alpha$ gene in the POA by altering DNA methylation status of its promoter.

In addition to the postnatal social, physiological and environmental stimuli, differences in the embryonic hormonal milieu can also have a lasting influence on the development of sociosexual behavior in the offspring brain, resulting in individual variation of behavioral characteristics in adulthood within the same sex. In polytocous animals, the sex-specific positioning of fetuses can result in a natural variation of the hormonal environment during intrauterine development due to diffusion of androgen from neighboring male siblings. During the late gestational period, both the blood and brain concentrations of testosterone are higher in female fetuses that grow between two male siblings (2M females) compared with growth between two female siblings (2F females) (vom Saal and Bronson, 1980; Pei et al., 2006). Corresponding to this different level of androgen exposure, $2 \mathrm{M}$ females show greater aggressiveness and less sexual receptivity than $2 \mathrm{~F}$ females in adulthood (vom Saal, 1984, 1989). It can be hypothesized that there may be intrauterine position-related differential ER $\alpha$ expression in the VMH, and ER $\alpha$ expression levels have been found to differ between $2 \mathrm{M}$ and $2 \mathrm{~F}$ female offspring (Mori et al., 2010), with ER $\alpha$ expression in the VMH being higher in $2 \mathrm{M}$ females than $2 \mathrm{~F}$ females. CpG sites across the ER $\alpha$ $0 \mathrm{~b}$ promoter region in the $\mathrm{VMH}$ were more densely methylated in $2 \mathrm{~F}$ females than in $2 \mathrm{M}$ females (Figure 1 ), showing a negative correlation between ER $\alpha$ expression levels in the VMH and DNA methylation frequency in the ER $\alpha$ promoter. These findings indicate that programming effects induced by the intrauterine position may be mediated by epigenetic modification.

\section{CONCLUSION}

$\mathrm{ER} \alpha$ expressed in specific brain areas controls various sociosexual behaviors in both sexes. The ER $\alpha$ level is correlated with differences in the magnitude of expression of these behaviors between the sexes and among individuals. Epigenetic programming appears to play central roles in the lasting regulation of ER $\alpha$ expression in response to the hormonal, social, and physiological environment during development. It will be of interest to determine the mechanisms that link these environmental cues to patterns of epigenetic modification in the $\mathrm{ER} \alpha$ promoter.

\section{REFERENCES}

Arnold, A. P., and Gorski, R. A. (1984). Gonadal steroid induction of structural sex differences in the central nervous system. Annu. Rev. Neurosci. 7, 413-442. doi: 10.1146/annurev.ne.07.030184.002213

Bicaku, E., Marchion, D. C., Schmitt, M. L., and Munster, P. N. (2008). Selective inhibition of histone deacetylase 2 silences progesterone receptor-mediated signaling. Cancer Res. 68, 1513-1519. doi: 10.1158/0008-5472.CAN-07-2822

Cameron, N., Del Corpo, A., Diorio, J., McAllister, K., Sharma, S., and Meaney, M. J. (2008a). Maternal programming of sexual behavior and hypothalamicpituitary-gonadal function in the female rat. PLoS ONE 3:e2210. doi: 10.1371/journal.pone.0002210
Cameron, N. M., Champagne, F. A., Parent, C., Fish, E. W., Ozaki-Kuroda, K., and Meaney, M. J. (2005). The programming of individual differences in defensive responses and reproductive strategies in the rat through variations in maternal care. Neurosci. Biobehav. Rev. 29, 843-865. doi: 10.1016/j.neubiorev. 2005.03.022

Cameron, N. M., Fish, E. W., and Meaney, M. J. (2008b). Maternal influences on the sexual behavior and reproductive success of the female rat. Horm. Behav. 54, 178-184. doi: 10.1016/j.yhbeh.2008.02.013

Champagne, F. A., Diorio, J., Sharma, S., and Meaney, M. J. (2001). Naturally occurring variations in maternal behavior in the rat are associated with differences in estrogen-inducible central oxytocin receptors. Proc. Natl. Acad. Sci. U.S.A. 98, 12736-12741. doi: 10.1073/pnas.221224598

Champagne, F. A., and Meaney, M. J. (2007). Transgenerational effects of social environment on variations in maternal care and behavioral response to novelty. Behav. Neurosci. 121, 1353-1363. doi: 10.1037/0735-7044. 121.6.1353

Champagne, F. A., Weaver, I. C., Diorio, J., Dymov, S., Szyf, M., and Meaney, M. J. (2006). Maternal care associated with methylation of the estrogen receptor-alphalb promoter and estrogen receptor-alpha expression in the medial preoptic area of female offspring. Endocrinology 147, 2909-2915. doi: 10.1210/en.2005-1119

Champagne, F. A., Weaver, I. C., Diorio, J., Sharma, S., and Meaney, M. J. (2003). Natural variations in maternal care are associated with estrogen receptor alpha expression and estrogen sensitivity in the medial preoptic area. Endocrinology 144, 4720-4724. doi: 10.1210/en.2003-0564

DonCarlos, L. L. (1996). Developmental profile and regulation of estrogen receptor (ER) mRNA expression in the preoptic area of prenatal rats. Brain Res. Dev. Brain Res. 94, 224-233. doi: 10.1016/S0165-3806(96) 80014-9

DonCarlos, L. L., and Handa, R. J. (1994). Developmental profile of estrogen receptor mRNA in the preoptic area of male and female neonatal rats. Brain Res. Dev. Brain Res. 79, 283-289. doi: 10.1016/0165-3806(94)90133-3

Edelmann, M. N., and Auger, A. P. (2011). Epigenetic impact of simulated maternal grooming on estrogen receptor alpha within the developing amygdala. Brain Behav. Immun. 25, 1299-1304. doi: 10.1016/j.bbi.2011. 02.009

Emery, D. E., and Sachs, B. D. (1976). Copulatory behavior in male rats with lesions in the bed nucleus of the stria terminalis. Physiol. Behav. 17, 803-806. doi: 10.1016/0031-9384(76)90044-5

Evans, R. M. (1988). The steroid and thyloid hormone receptor superfamily. Science 240, 889-895. doi: 10.1126/science.3283939

Felsenfeld, G., and Groudine, M. (2003). Controlling the double helix. Nature 421, 448-453. doi: 10.1038/nature01411

Francis, D. D., Champagne, F. A., Liu, D., and Meaney, M. J. (1999). Maternal care, gene expression, and the development of individual differences in stress reactivity. Ann. N.Y. Acad. Sci. 896, 66-84. doi: 10.1111/j.1749-6632.1999. tb08106.x

Freyschuss, B., and Grandien, K. (1996). The $5^{\prime}$ flank of the rat estrogen receptor gene: structural characterization and evidence for tissue- and species-specific promoter utilization. J. Mol. Endocrinol. 17, 197-206. doi: 10.1677/jme.0.0170197

Graff, J., and Tsai, L. H. (2013). Histone acetylation: molecular mnemonics on the chromatin. Nat. Rev. Neurosci. 14, 97-111. doi: 10.1038/nrn3427

Kato, J., Hirata, S., Koh, T., Yamada-Mouri, N., Hosh, K., and Okinaga, S. (1998). The multiple untranslated first exons and promoters system of the oestrogen receptor gene in the brain and peripheral tissues of the rat and monkey and the developing rat cerebral cortex. J. Steroid Biochem. Mol. Biol. 65, 281-293. doi: 10.1016/S0960-0760(97)00184-2

Kawata, M. (1995). Roles of steroid hormones and their receptors in structural organization in the nervous system. Neurosci. Res. 24, 1-46. doi: 10.1016/01680102(96)81278-8

Keverne, E. B., and Curley, J. P. (2008). Epigenetics, brain evolution and behaviour. Front. Neuroendocrinol. 29, 398-412. doi: 10.1016/j.yfrne.2008.03.001

Koehler, K. F., Helguero, L. A., Haldosen, L. A., Warner, M., and Gustafsson, J. A. (2005). Reflections on the discovery and significance of estrogen receptor beta. Endocr. Rev. 26, 465-478. doi: 10.1210/er.2004-0027

Kos, M., Reid, G., Denger, S., and Gannon, F. (2001). Minireview: genomic organization of the human ERalpha gene promoter region. Mol. Endocrinol. 15, 2057-2063. doi: 10.1210/mend.15.12.0731 
Kouzarides, T. (2007). Chromatin modifications and their function. Cell 128, 693-705. doi: 10.1016/j.cell.2007.02.005

Kurian, J. R., Olesen, K. M., and Auger, A. P. (2010). Sex differences in epigenetic regulation of the estrogen receptor-alpha promoter within the developing preoptic area. Endocrinology. 151, 2297-2305. doi: 10.1210/en. 2009-0649

Larsson, K., and Heimer, L. (1964). Mating behaviour of male rats after lesions in the preoptic area. Nature 202, 413-414. doi: 10.1038/202413a0

Leong, H., Sloan, J. R., Nash, P. D., and Greene, G. L. (2005). Recruitment of histone deacetylase 4 to the $\mathrm{N}$-terminal region of estrogen receptor alpha. Mol. Endocrinol. 19, 2930-2942. doi: 10.1210/me.2005-0178

Liu, D., Diorio, J., Day, J. C., Francis, D. D., and Meaney, M. J. (2000). Maternal care, hippocampal synaptogenesis and cognitive development in rats. Nat. Neurosci. 3, 799-806. doi: $10.1038 / 77702$

Martin, C., and Zhang, Y. (2005). The diverse functions of histone lysine methylation. Nat. Rev. Mol. Cell Biol. 6, 838-849. doi: 10.1038/nrm1761

Matsuda, K. I., Mori, H., and Kawata, M. (2012). Epigenetic mechanisms are involved in sexual differentiation of the brain. Rev. Endocr. Metab. Disord. 13, 163-171. doi: 10.1007/s11154-012-9202-z

Matsuda, K. I., Mori, H., Nugent, B. M., Pfaff, D. W., McCarthy, M. M., and Kawata, M. (2011). Histone deacetylation during brain development is essential for permanent masculinization of sexual behavior. Endocrinology 152, 2760-2767. doi: 10.1210/en.2011-0193

Matsuda, K. I., Ochiai, I., Nishi, M., and Kawata, M. (2002). Colocalization and ligand-dependent discrete distribution of the estrogen receptor (ER)alpha and ERbeta. Mol. Endocrinol. 16, 2215-2230. doi: 10.1210/me.2002-0110

Matsuda, K. I., Sakamoto, H., and Kawata, M. (2008). Androgen action in the brain and spinal cord for the regulation of male sexual behaviors. Curr. Opin. Pharmacol. 8, 747-751. doi: 10.1016/j.coph.2008.08.010

McCarthy, M. M. (2008). Estradiol and the developing brain. Physiol. Rev. 88, 91-124 doi: 10.1152/physrev.00010.2007

McCarthy, M. M., and Crews, D. (2008). Epigenetics-new frontiers in neuroendocrinology. Front. Neuroendocrinol. 29, 341-343. doi: 10.1016/j.yfrne.2008.01.002

Moore, C. L. (1992). The role of maternal stimulation in the development of sexual behavior and its neural basis. Ann. N.Y. Acad. Sci. 662, 160-177. doi: 10.1111/j.1749-6632.1992.tb22859.x

Mori, H., Matsuda, K. I., Tsukahara, S., and Kawata, M. (2010). Intrauterine position affects estrogen receptor alpha expression in the ventromedial nucleus of the hypothalamus via promoter DNA methylation. Endocrinology 151, 5775-5581. doi: 10.1210/en.2010-0646

Murray, E. K., Hien, A., de Vries, G. J., and Forger, N. G. (2009). Epigenetic control of sexual differentiation of the bed nucleus of the stria terminalis. Endocrinology 150, 4241-4247. doi: 10.1210/en.2009-0458

Musatov, S., Chen, W., Pfaff, D. W., Kaplitt, M. G., and Ogawa, S. (2006). RNAimediated silencing of estrogen receptor $\{$ alpha $\}$ in the ventromedial nucleus of hypothalamus abolishes female sexual behaviors. Proc. Natl. Acad. Sci. U.S.A. 103, 10456-10460. doi: 10.1073/pnas.0603045103

Nakao, M. (2001). Epigenetics: interaction of DNA methylation and chromatin. Gene 278, 25-31. doi: 10.1016/S0378-1119(01)00721-1

Numan, M. A. (1996). Lesion and neuroanatomical tract-tracing analysis of the role of the bed nucleus of the stria terminalis in retrieval behavior and other aspects of maternal responsiveness in rats. Dev. Psychobiol. 29, 23-51.

Numan, M., and Woodside, B. (2010). Maternity: neural mechanisms, motivational processes, and physiological adaptations. Behav. Neurosci. 124, 715-741. doi: $10.1037 / \mathrm{a} 0021548$

Ogawa, S., Eng, V., Taylor, J., Lubahn, D. B., Korach, K. S., and Pfaff, D. W. (1998a). Roles of estrogen receptor-alpha gene expression in reproduction-related behaviors in female mice. Endocrinology 139, 5070-5081.

Ogawa, S., Lubahn, D. B., Korach, K. S., and Pfaff, D. W. (1997). Behavioral effects of estrogen receptor gene disruption in male mice. Proc. Natl. Acad. Sci. U.S.A. 94, 1476-1481. doi: 10.1073/pnas.94.4.1476

Ogawa, S., Taylor, J. A., Lubahn, D. B., Korach, K. S., and Pfaff, D. W. (1996). Reversal of sex roles in genetic female mice by disruption of estrogen receptor gene. Neuroendocrinology 64, 467-470. doi: 10.1159/000127154

Ogawa, S., Washburn, T. F., Taylor, J., Lubahn, D. B., Korach, K. S., and Pfaff, D. W. (1998b). Modifications of testosterone-dependent behaviors by estrogen receptor-alpha gene disruption in male mice. Endocrinology 139, 5058-5069.
Parker, M. G. (1995). Structure and function of estrogen receptors. Vitam. Horm. 51, 267-287. doi: 10.1016/S0083-6729(08)61041-9

Pei, M., Matsuda, K. I., Sakamoto, H., and Kawata, M. (2006). Intrauterine proximity to male fetuses affects the morphology of the sexually dimorphic nucleus of the preoptic area in the adult rat brain. Eur. J. Neurosci. 23, 1234-1240. doi: 10.1111/j.1460-9568.2006.04661.x

Pena, C. J., Neugut, Y. D., and Champagne, F. A. (2013). Developmental timing of the effects of maternal care on gene expression and epigenetic regulation of hormone receptor levels in female rats. Endocrinology 154, 4340-4351. doi: 10.1210/en.2013-1595

Prior, K. M., Meaney, M. J., and Cameron, N. M. (2013). Variations in maternal care associated with differences in female rat reproductive behavior in a groupmating environment. Dev. Psychobiol. 55, 838-848. doi: 10.1002/dev.21075

Ribeiro, A. C., Musatov, S., Shteyler, A., Simanduyev, S., and Arrieta-Cruz, I. (2012). siRNA silencing of estrogen receptor-alpha expression specifically in medial preoptic area neurons abolishes maternal care in female mice. Proc. Natl. Acad. Sci. U.S.A. 109, 16324-16329. doi: 10.1073/pnas.1214094109

Rissman, E. F., Wersinger, S. R., Taylar, J. A., and Lubahn, D. B. (1997). Estrogen receptor function as revealed by knockout studies: neuroendocrine and behavioral aspects. Horm. Behav. 31, 232-243. doi: 10.1006/hbeh.1997.1390

Sakamoto, H., Takahashi, H., Matsuda, K. I., Nishi, M., and Takanami, K. (2012). Rapid signaling of steroid hormones in the vertebrate nervous system. Front. Biosci. (Landmark Ed) 17, 996-1019. doi: 10.2741/3970

Sano, K., Tsuda, M. C., Musatov, S., Sakamoto, T., and Ogawa, S. (2013). Differential effects of site-specific knockdown of estrogen receptor alpha in the medial amygdala, medial pre-optic area, and ventromedial nucleus of the hypothalamus on sexual and aggressive behavior of male mice. Eur. J. Neurosci. 37, 1308-1319. doi: 10.1111/ejn.12131

Schwarz, J. M., Nugent, B. M., and McCarthy, M. M. (2010). Developmental and hormone-induced epigenetic changes to estrogen and progesterone receptor genes in brain are dynamic across the life span. Endocrinology 151, 4871-4781. doi: 10.1210/en.2010-0142

Scordalakes, E. M., and Rissman, E. F. (2003). Aggression in male lacking functional estrogen receptor $\alpha$. Behav. Neurosci. 44, 427-434. doi: 10.1037/07357044.117.1.38

Spiteri, T., Musatov, S., Ogawa, S., Ribeiro, A., Pfaff, D. W., and Agmo, A. (2010a). Estrogen-induced sexual incentive motivation, proceptivity and receptivity depend on a functional estrogen receptor alpha in the ventromedial nucleus of the hypothalamus but not in the amygdala. Neuroendocrinology 91, 142-154. doi: $10.1159 / 000255766$

Spiteri, T., Musatov, S., Ogawa, S., Ribeiro, A., Pfaff, D. W., and Agmo, A. (2010b). The role of the estrogen receptor $\alpha$ in the medial amygdala and ventromedial nucleus of the hypothalamus in social recognition, anxiety and aggression. Behav. Brain Res. 210, 211-220. doi: 10.1016/j.bbr.2010.02.033

Spiteri, T., Ogawa, S., Musatov, S., Pfaff, D. W., and Agmo, A. (2012). The role of the estrogen receptor alpha in the medial preoptic area in sexual incentive motivation, proceptivity and receptivity, anxiety, and wheel running in female rats. Behav Brain Res. 230, 11-20. doi: 10.1016/j.bbr.2012.01.048

Tetel, M. J., and Pfaff, D. W. (2010). Contributions of estrogen receptor,- $\alpha$, and estrogen receptor- $\beta$ to the regulation of behavior. Biochim. Biophys. Acta 1800, 1084-1089. doi: 10.1016/j.bbagen.2010.01.008

Vasudevan, N., and Pfaff, D. W. (2008). Non-genomic actions of estrogens and their interaction with genomic actions in the brain. Front. Neuroendocrinol. 29, 238-257. doi: 10.1016/j.yfrne.2007.08.003

vom Saal, F. S. (1984). The intrauterine position phenomenon: effects on physiology, aggressive behavior and population dynamics in house mice. Prog. Clin. Biol. Res. 169, 135-179.

vom Saal, F. S. (1989). Sexual differentiation in litter-bearing mammals: influence of sex of adjacent fetuses in utero. J. Anim. Sci. 67, 1824-1840.

vom Saal, F. S., and Bronson, F. H. (1980). Sexual characteristics of adult female mice are correlated with their blood testosterone levels during prenatal development. Science 208, 597-599. doi: 10.1126/science.7367881

Wersinger, S. R., Sannen, K., Villalba, C., Lubahn, D. B., Rissman, E. F., and De Vries, G. J. (1997). Masculine sexual behavior is disrupted in male and female mice lacking a functional estrogen receptor $\alpha$ gene. Horm. Behav. 32, 176-183.

Wilson, M. E., Westberry, J. M., and Prewitt, A. K. (2008). Dynamic regulation of estrogen receptor-alpha gene expression in the brain: a role for promoter methylation? Front. Neuroendocrinol. 29, 375-385. doi: 10.1016/j.yfrne. 2008.03.002 
Yokosuka, M., Okamura, H., and Hayashi, S. (1997). Postnatal development and sex difference in neurons containing estrogen receptor-alpha immunoreactivity in the preoptic brain, the diencephalon, and the amygdala in the rat. J. Comp. Neurol. 389, 81-93.

Zhang, Y., and Reinberg, D. (2001). Transcription regulation by histone methylation: interplay between different covalent modifications of the core histone tails. Genes Dev. 15, 2343-2360. doi: 10.1101/gad. 927301

Conflict of Interest Statement: The author declares that the research was conducted in the absence of any commercial or financial relationships that could be construed as a potential conflict of interest.
Received: 30 April 2014; accepted: 09 October 2014; published online: 28 October 2014. Citation: Matsuda KI (2014) Epigenetic changes in the estrogen receptor $\alpha$ gene promoter: implications in sociosexual behaviors. Front. Neurosci. 8:344. doi: 10.3389/ fnins.2014.00344

This article was submitted to Neuroendocrine Science, a section of the journal Frontiers in Neuroscience.

Copyright (c) 2014 Matsuda. This is an open-access article distributed under the terms of the Creative Commons Attribution License (CC BY). The use, distribution or reproduction in other forums is permitted, provided the original author(s) or licensor are credited and that the original publication in this journal is cited, in accordance with accepted academic practice. No use, distribution or reproduction is permitted which does not comply with these terms. 